\title{
A Spiritual Inheritance: Black Catholics in Southern Maryland
}

Author: Laura E. Masur

Source: Engaging Sources: The Tradition and Future of Collecting History in the Society of Jesus (Proceedings of the Symposium held at Boston College, June 11-13, 2019)

Edited by: Cristiano Casalini, Emanuele Colombo, and Seth Meehan

ISBN: 978-1-947617-09-4

Published by: Institute of Jesuit Sources

Originally Published: March 1, 2021

https://doi.org/10.51238/ISJS.2019.10

Provided in Open Access by the Institute for Advanced Jesuit Studies at Boston College.

The Institute of Jesuit Sources, specializes in preserving, maintaining, and expanding for scholars around the world important texts and studies in Jesuit history, spirituality, and pedagogy.

Visit our website at https://jesuitsources.bc.edu 


\title{
A Spiritual Inheritance: Black Catholics in Southern Maryland
}

\author{
LAURA E. MASUR
}

\begin{abstract}
An old negro, the white-washer about St. Thomas', told me a nice story of Father Hunter. One night, it was pitch dark, two young men came from Virginia to call Father Hunter to a sick man. They were very respectful and spoke very little; one of them had a lantern to show the way. They entered the skiff and rowed him across; the Potomac here is about eight miles wide. After the Father had attended to the sick man, they brought him back in the same way. Now when Father Hunter had stepped ashore, he turned around to thank them, when lo and behold, men, skiff and lantern had disappeared; they were two angels. ${ }^{1}$
\end{abstract}

Tales like this are exceptionally rare. In the above passage, an aged laborer recounts a story about Father George Hunter, a Jesuit priest stationed at St. Thomas/Portobacco plantation in Maryland between 1747 and 1779. Even though the passage was written by Father Joseph Zwinge, who managed the Jesuits' former plantations in the early twentieth century, the storyteller's narrative voice is clear. He relates a story that was clearly passed on as an oral tradition over several generations - for at least 120 years after Hunter's death—-because it was important. Perhaps the tradition was repeated to remind listeners about the ways that angels could intervene in the world of the living, or of the importance of rituals surrounding death; these concepts are important in many African and African American spiritual traditions as well as in Catholicism. ${ }^{2}$

Enslaved African Americans populated Chesapeake plantation landscapes beginning in the seventeenth century. While many of these individuals adapted spiritual beliefs and practices from their homelands, many also converted to

I would like to express sincere thanks to Sara Rivers Cofield, Patricia Samford, Silas Hurry, Kristin Montaperto, Michael Lucas, Garrett Fesler, Jolene Smith, Leslie Cooper, and Lily Carhart, who helped me to track down the artifacts discussed in this article. Many thanks also to Mary Beaudry and Kimberly Arkin for comments on an earlier draft, and to the two anonymous reviewers, whose helpful suggestions have greatly improved the article.

${ }^{1}$ Joseph Zwinge, "The Jesuit Farms in Maryland: Facts and Anecdotes; The Negro Slaves," Woodstock Letters 41, no. 2 (1912): 195-222, here 218.

2 Albert J. Raboteau, Slave Religion: The "Invisible Institution" in the Antebellum South (New York: Oxford University Press, 1978). 
Christianity. The Society of Jesus's prominent role in Maryland history also engendered close relationships with enslaved African and African American Catholics across centuries. Although few of their stories have been documented, ${ }^{3}$ Black Catholics - both enslaved and free - filled the Society of Jesus's chapels and cemeteries spread throughout rural Maryland. They practiced Catholicism, passing their faith onto their children, despite the Jesuits' reluctance to recognize their full rights as human beings or disrupt the status quo of racial inequality.

Why did African Americans embrace Catholicism in Maryland? Here, I examine two sources - Jesuit missionary accounts and material culture - in order to explore the varied beliefs and practices of Black Catholics in Maryland between the mid-eighteenth and mid-twentieth centuries. The Maryland Jesuits' accounts of rural missions, paired with the archaeological record and twentieth-century oral histories, provide a rich resource for discussing lived religion among African American Catholics. Archaeological artifacts, in particular, provide context and nuance to the way that rosaries, crosses, medals, and statues were used by African Americans during this period. While we cannot know with certainty what these objects meant to individuals, Jesuit accounts and oral histories provide a sense of how Black Catholics might have understood them. Catholic objects can be read as nodes in a missionary network, as markers of negotiation, and as vessels used to commune with the supernatural presences of gods, saints, and angels. ${ }^{4}$

It is clear that people of African descent used Catholicism and Catholic objects to negotiate enslavement and its racial legacies in order to promote their temporal and spiritual well-being. While these negotiations were diverse and multifaceted, Catholicism was probably attractive to African Americans for four main reasons: (1) the theological role of saints and spirits, and their embodiment in material objects, was not incongruent with West African spiritual practices; (2) Catholicism offered an outlet for deep spiritual connections through prayer, and a recognition of human dignity through access to sacraments; (3) religious practice enabled communities to build strong and uplifting social networks, with the support of the Catholic hierarchy; and (4) the decision to practice Catholicism provided a means of negotiating power relationships and gaining access to economic opportunities. While Jesuit slaveholding is regarded as a failure of accommodation, ${ }^{5}$ its

\footnotetext{
${ }^{3}$ But see Beatriz Betancourt Hardy, ““The Papists [...] Have Shewn a Laudable Care and Concern': Catholicism, Anglicanism, and Slave Religion in Colonial Maryland," Maryland Historical Magazine 98, no. 1 (2003): 4-33.

${ }^{4}$ See Robert A. Orsi, History and Presence (Cambridge, MA: Harvard University Press, 2016). For an archaeological application, see Laura E. Masur, "Symbol or Presence? Archaeology and the Materiality of Catholic Devotions," U.S. Catholic Historian 38, no. 2 (2020): 1-2; https://doi.org/10.1353/cht.2020.0009 (accessed August 5, 2020).

${ }^{5}$ Edward F. Beckett, "Listening to Our History: Inculturation and Jesuit Slaveholding," Studies in the Spirituality of Jesuits 28, no. 5 (1996): 1-48. Thomas Murphy, Jesuit Slaveholding in Maryland, 1717-1838 (New York: Routledge, 2001).
} 
consequences in Maryland are nonetheless complex. The role of Jesuit ministry to African Americans laid the foundations for Black Catholic spirituality, one of the most significant legacies of the Maryland mission. ${ }^{6}$

\section{Archaeological Approaches to Spirituality in the Black Atlantic}

African gods, Albert Raboteau notes, "were carried in the memories of enslaved Africans across the Atlantic."7 West African spiritual traditions typically included a High God or Supreme Creator, but most religious interactions involved lesser gods and ancestral spirits. These gods and spirits permeated every facet of life. Relationships with gods involved sacrifices, divination, and spirit possession; gods dwelt in shrines, which could be places or objects. Objects known as fetishes, charms, or amulets were also used as a part of ritual interactions with gods and spirits. ${ }^{8}$

Numerous historical archaeologists have explored connections between West or West Central African spirituality and archaeological collections from North America and the Caribbean. These interpretations often follow the theories of anthropologist Melville Herskovits, highlighting continuities between West Africa and the Americas, referred to as "Africanisms." For example, Leland Ferguson interprets circled crosses on locally produced earthenware ceramics (colonoware) as evidence for the continuation of Bakongo-influenced water cults in South Carolina. These vessels, found archaeologically near rivers, were involved in the creation and containment of Kongo sacred medicine or minkisi (singular, nkisi). ${ }^{9}$ The most extensive body of literature addresses the discovery of bundles or caches, usually concealed within dwellings, adjacent to foundations, or near entryways such as doors or chimneys. Mark Leone and Gladys-Marie Fry use folklore to interpret artifacts such as pins, beads, and crystals as evidence of conjuration and divination among African Americans living on plantations in the eighteenth- and nineteenth-century Chesapeake. ${ }^{10}$ Patricia Samford synthesizes evidence of subfloor pits from colonial slave quarters in Virginia, arguing that some of these

\footnotetext{
${ }^{6}$ Francis Michael Walsh, "Resurrection: The Story of the Saint Inigoes Mission, 1634-1994" (Unpublished Manuscript, 1997). On file at Historic St. Mary’s City.

${ }^{7}$ Raboteau, Slave Religion, 16.

${ }^{8}$ Raboteau, Slave Religion, 8-16.

${ }^{9}$ Melville J. Herskovits, The Myth of the Negro Past (New York: Harper \& Brothers, 1941). Leland G. Ferguson, Uncommon Ground: Archaeology and Early African America, 1650-1800 (Washington, DC: Smithsonian Institution Press, 1992).

${ }^{10}$ Mark P. Leone and Gladys-Marie Fry, "Conjuring in the Big House Kitchen: An Interpretation of African American Belief Systems Based on the Uses of Archaeology and Folklore Sources," Journal of American Folklore 112, no. 445 (1999): 372-403; https://doi.org/10.2307/541368 (accessed August 5, 2020).
} 
archaeological features were used as West African-style shrines. For example, pits located inside eighteenth-century structures at Utopia Quarter in James City County contained intentionally placed wine bottles, bones, pipes, shells, microbotanical evidence of grapes or wine, and numerous other objects. These objects had ritual significance in West African traditions, and Samford argues that they confirm the continued practice of traditions such as charms and spirit bundles into the eighteenth century. ${ }^{11}$

Archaeological researchers often acknowledge the complexity of cultural mixture by employing theories of creolization or ethnogenesis, noting changes as West African spirituality was adapted to life in the Americas. Indeed, archaeological evidence attests that "folk" practices were not unique to African Americans but were also common among European immigrants. ${ }^{12}$ Moreover, careful analysis of archaeological context is essential for determining the complex meaning of ritual

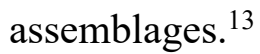

Although connections with Africa are a recurrent theme in archaeological literature on caches, the inhabitants of associated residences can often be linked to specific Christian churches. A possible ritual cache was found near a hearth in the house of Barbados-born Quaker William Cooper, who lived in Delaware during the early nineteenth century. Ritually concealed objects were also found in the late nineteenth-century New Jersey house of Presbyterian sexton William Mann. ${ }^{14}$ Laurie Wilkie identified several Catholic artifacts - a brass rosary medal, a medal depicting Christ, and a porcelain nativity figure - among other ritual objects in a c.1880-1910 assemblage from Oakley Plantation in Louisiana. These artifacts are associated with an African American Baptist woman named Silvia Freeman, showing how African/European and Protestant/Catholic traditions could be integrated. Wilkie argues that objects associated with Catholic saints may have been appropriated into Freeman's traditions because, like West African charms, the objects

\footnotetext{
${ }^{11}$ Patricia Samford, Subfloor Pits and the Archaeology of Slavery in Colonial Virginia (Tuscaloosa: University of Alabama Press, 2007), 149-73.

${ }^{12}$ Christopher Fennell, Crossroads and Cosmologies: Diasporas and Ethnogenesis in the New World (Gainesville: University Press of Florida, 2007). Sara Rivers Cofield, "Keeping a Crooked Sixpence: Coin Magic and Religion in the Colonial Chesapeake," Historical Archaeology 48, no. 3 (2014): 84-105.

${ }^{13}$ Matthew Reeves, "Mundane or Spiritual? The Interpretation of Glass Bottle Containers Found on Two Sites of the African Diaspora," in Materialities of Ritual in the Black Atlantic, ed. Akinwumi Ogundiran and Paula Saunders (Bloomington: Indiana University Press, 2014), 176-97.

${ }^{14}$ Michael J. Gall, Glenn R. Modica, and Tabitha C. Hilliard, "Navigation and Negotiation: Adaptive Strategies of a Free African American Family in Central Delaware," in Archaeologies of African American Life in the Upper Mid-Atlantic, ed. Michael J. Gall and Richard F. Veit (Tuscaloosa: University of Alabama Press, 2017), 71-87; Megan E. Springate, "Double Consciousness and the Intersections of Beliefs in an African American Home in Northern New Jersey," Historical Archaeology 48, no. 3 (2014): 125-43.
} 
contained spiritual power. ${ }^{15}$ Moreover, two double-barred crosses are among c.1680-1720 Charles Town, Maryland ritual deposits. Michael Lucas describes the difficulty of disentangling the spiritual practices represented by these objects, given the creolization of European, African, and American Indian cultures. ${ }^{16}$

It is clear from these examples that the continuation of West African spiritual practices was not considered antithetical to the practice of Christianity. ${ }^{17}$ Indeed, some enslaved Africans in the Americas had been introduced to Christianity through West African missions. The Society of Jesus established missions in Kongo and Angola, then under Portuguese influence, during the sixteenth and seventeenth centuries. Their ministries led to thousands of conversions in Angola. ${ }^{18}$ At the request of the Kongolese king, Portuguese Capuchins re-established missions during the eighteenth century. The Christian cross, recognized by the Kongolese as $n k i s i$ (holy), enabled the integration of belief systems and the naturalization of Christianity as a Kongolese tradition. ${ }^{19}$ The amalgamation and coexistence of Christianity and West African spirituality is well documented in traditions such as Vodou, wherein African gods were merged with Catholic saints. ${ }^{20}$ These traditions were also built on shared notions of the materiality of interactions with the supernatural, which might include venerating images, lighting candles, and observing feasts. So too the concept of presence was common in African and Catholic traditions: gods and spirits could reside in particular places or objects. Christ, the Virgin

${ }^{15}$ Laurie A. Wilkie, "Magic and Empowerment on the Plantation: An Archaeological Consideration of African-American World View," Southeastern Archaeology 14, no. 2 (1995): 136-48.

${ }^{16}$ Michael T. Lucas, "Empowered Objects: Material Expressions of Spiritual Beliefs in the Colonial Chesapeake Region," Historical Archaeology 48, no. 3 (2014): 106-24; https://doi.org/10.1007/BF03376939 (accessed August 5, 2020).

${ }^{17}$ See also Lu Ann De Cunzo, "African American Cultures and Place in the Greater Delaware Valley Borderland, 1620s to 1920s," in Gall and Veit, Archaeologies of African American Life, 198-212, here 211.

${ }^{18}$ Festo Mkenda, "Jesuit Historiography in Africa," Jesuit Historiography Online, ed. Robert A. Maryks, January 2017; https://referenceworks.brillonline.com/entries/jesuit-historiographyonline/jesuit-historiography-in-africa-COM_192529 (accessed August 5, 2020). Mkenda, "Jesuits and Africa," Oxford Handbooks Online, August 2016; https://doi.org/10.1093/oxfordhb/9780199935420.013.56 (accessed August 5, 2020). John K Thornton, "Conquest and Theology," Journal of Jesuit Studies 1, no. 2 (2014): 245-59; https://doi.org/10.1163/2214133200102006 (accessed August 5, 2020).

${ }^{19}$ Cécile Fromont, "Under the Sign of the Cross in the Kingdom of Kongo: Religious Conversion and Visual Correlation in Early Modern Central Africa," RES: Anthropology and Aesthetics, no. 59/60 (2011): 109-23. It is likely that Christian missions in Africa influenced the spirituality of Africans who were enslaved and brought to the Americas. By the 1730s, the largest group of captive Africans arriving in the Chesapeake came from Angola. A man named "Portuguese Joseph," enslaved by Rev. Mr. Lewis at the Jesuits' St. Inigoes plantation, was listed on the St. Inigoes parish register in 1767-69. Joseph's name alludes to his role as an "Atlantic Creole," an individual who possessed knowledge and experience of the New World, European languages, Christianity, and European culture. Ira Berlin, Many Thousands Gone: The First Two Centuries of Slavery in North America (Cambridge, MA: Harvard University Press, 1998), 29-46, 114.

${ }^{20}$ Karen McCarthy Brown, "Vodou," in Encyclopedia of Religion, ed. Lindsay Jones, 2nd ed. (Detroit, MI: Macmillan Reference USA, 2005), 14:9634-39; Raboteau, Slave Religion, 22-23. 
Mary, guardian angels, and patron saints were intercessors in ways that were similar to gods and ancestral spirits, with powers related to their particular patronage. Furthermore, material substances, whether brandy sacrificed in a subfloor pit or wine consecrated as the blood of Christ, were integral to interactions with the supernatural.

\section{Plantation as Mission}

Whether or not they continued to practice West African traditions, some enslaved Africans in colonial Maryland converted to Catholicism. African Americans are present on the earliest Catholic sacramental records in British colonial North America. $^{21}$ In December 1766, Nicholas and Abigail, "negroes of Mrs. Blake," were married at Wye on the eastern shore of Maryland. ${ }^{22}$ Philip, a man enslaved by William Heard, was baptized in St. Mary's County in June 1767. Black Catholics also served as sponsors or godparents, playing important spiritual and social roles within their communities. In January 1771, an unnamed person enslaved by the Taney family was baptized, the godparent or sponsor noted only as "nig." 23 Fourteen African Americans "belonging to Rev. Mr. Lewis," the mission superior, are listed in the Jesuits' 1767-69 St. Inigoes congregation: Betty, Matthew, Betty Jr., Tom, Susan, William, Abraham, Nacy, Brigit, James, Abraham, Ann, Portuguese Joseph, and George Mingo. ${ }^{24}$ This is a majority of the enslaved population at St. Inigoes plantation, which numbered around twenty at that time. ${ }^{25}$

Jesuit priests had complex and varied relationships with African Americans on plantations, reflecting their role as both spiritual and temporal authorities. These

\footnotetext{
${ }^{21}$ Christina, an adult woman who was most likely enslaved in the household of a Dr. Brown of Philadelphia, was baptized in the spring of 1744. Elizabeth Petty Bentley, ed., The Goshenhoppen Registers, 1741-1819: Registers of Baptisms, Marriages, and Deaths of the Catholic Mission at Goshenhoppen (Bally), Washington Township, Berks County, Pennsylvania (Baltimore: Genealogical Pub. Co., 1984), 1:7.

22 "Marriage Register for Southern Maryland, the Eastern Shore, and Delaware, 1760-1802 [transcription]." Georgetown Slavery Archive (GSA) 46, 2. Transcript of Marriage Registers (17631802) of Joseph Mosley, S.J. and John Bolton, S.J., Box 31, Folder 4, Maryland Province Archives of the Society of Jesus (MPA), Georgetown University Archives, Washington, DC.

23 "Baptisms in St. Mary's County, MD: 1766-1794, Recorded by Rev. James Walton, S.J. [transcription]." GSA 49, 2, 15. Extract (typescript) from the diary of James Walton, Box 4, Folder 3, MPA.

${ }^{24}$ Edwin Warfield Beitzell, The Jesuit Missions of St. Mary's County, Maryland (Abell, MD: St. Mary's County Bicentennial Commission, 1959), 76.

${ }^{25}$ The population numbered nineteen in 1760 , twenty in 1765 , and twenty-eight in 1790 . "St. Inigoes Enslaved Community, c.1760." GSA 323. Almanac, Box 3, Folder 15, MPA. Thomas Hughes, History of the Society of Jesus in North America: Colonial and Federal, documents, vol. 1, part 1, nos. 1-140 (1605-1838) (London: Burrows Brothers Company, Longmans, Green, and Co., 1908), document 1, part 1, 335-37; http://archive.org/details/historyofsociety1717hugh (accessed August 5, 2020). US Federal census 1790.
} 
relationships varied by time, place, and individual and underline enslaved Africans' choices to practice Catholicism as well as Jesuits' efforts to cultivate and control their morality. Jesuit priests and plantation managers made concerted efforts to instill enslaved Africans with Catholic beliefs and values by issuing instructions about the observance of Sundays and holy days, providing catechetical instruction and spiritual guidance, and in several cases, encouraging participation in sodalities. ${ }^{26}$ Father Fidele de Grivel reported the religious practices of African Americans surrounding the Jesuits' St. Thomas plantation in an 1831 letter. Over several weeks in January, he "confessed 40 Negroes. [...] They came from 2, 4, and 6 miles by foot, while fasting, despite the rain or the snow." This was apparently a free choice, "because their masters, even the Protestants, do not bother them on the subject of their religious duties." Although illiterate, the African Americans who came to St. Thomas were familiar with tenets of the Catholic faith, "very capable of being admitted into Communion, well-knowing how to discern this heavenly bread." Parents taught their children prayers, and Father Francis Neale instructed children in the catechism of the Catholic Church. ${ }^{27}$ The size of the congregation at St. Inigoes doubled between 1816 and 1838. While much of this growth came from the conversion of Protestants, the pastor, Father Joseph Carberry, noted that "all most all of the Blacks have imbraced [sic] the Catholic faith." ${ }^{28}$ In an 1854 report about St. Inigoes parish, Father Thomas Lilly noted that some people enslaved by Protestants were not permitted to marry legally, so he secretly and sacramentally officiated their marriages. ${ }^{29}$ In these cases, the dignity that accompanied an official recognition of marriage by a Catholic priest may have provided a powerful incentive for practicing Catholicism.

Converting to Catholicism was probably not a uniquely spiritual choice. Particularly on Jesuit plantations, there were material advantages to conversion. These advantages are best described as an asymmetrical — but nonetheless reciprocal-connection known as a patron-client relationship. A patron (in this case, a Jesuit landowner) provided economic opportunity and protection to the client (an enslaved or free laborer), who "paid" the patron with support and loyalty, in this

\footnotetext{
${ }^{26}$ Peter C. Finn, "The Slaves of the Jesuits in Maryland" (Master's thesis, Washington, DC, Georgetown University, Department of History, 1974), 45-46.

27 "Slavery at St. Thomas Manor: Fr. Grivel to Fr. Roothaan, 1831." GSA 296. ARSI, Provincia Maryland, 1004-II, 123-28.

${ }^{28}$ Tricia T. Pyne, "2.9 Historical Background," in Phase I Archaeological Investigations Aboard Webster Field Annex: NAS PAX, St. Mary's County, Maryland; Report Presented to Natural Resources Branch Environmental and Natural Resources Division Department of Public Works Naval Air Station Patuxent River, ed. Laura J. Galke and Alyssa L. Loney (St. Leonard, MD: Jefferson Patterson Park and Museum Maryland Historic Trust, 2000), 44.

${ }^{29}$ Walsh, "Resurrection," 129. Finn, "Slaves of the Jesuits in Maryland," 49-51 also addresses Jesuit perspectives on the marriage of enslaved Africans.
} 
case, loyalty to Jesus Christ through conversion and religious observance. ${ }^{30}$ This social contract ensured the Jesuits would protect and care for the client and their family.

On Jesuit plantations, showing loyalty to the Jesuits and obeying religious and moral rules was central to maintaining a patron-client relationship. Missionaries made efforts to ensure that enslaved families were not separated, even when sold, ${ }^{31}$ and marked births, deaths, and other rites of passage with the dignity of sacramental recognition. According to local tradition, an enslaved man named Matthias Mahoney ensured the protection of enslaved women and Jesuit property during an 1814 British raid at St. Inigoes, and as a result, the Jesuits protected his family from the 1838 slave sale. Louisa Mahoney Mason and her children remained enslaved by the Jesuits until 1864 and continued to live and work at St. Inigoes thereafter. "Aunt Louisa" is remembered above all for her loyalty and piety; the Jesuits offered a requiem Mass when she passed away in 1909. According to one oral history, Louisa Mason made the Jesuits promise to bury her in the St. Inigoes cemetery because, she said, "I think I deserve to be there." 32 In the early twentieth century, Jesuit procurator Joseph Zwinge preferentially leased oystering rights to tenants or residents of the Black community at Beachville, including Louisa's son, Robert Mason. ${ }^{33}$ Zwinge also allowed former slaves George and Sarah Brown to build a retirement cabin near their former home at Cedar Point Neck in Charles County. ${ }^{34}$

In contrast, violating Catholic morality-particularly sexual moralityconstituted a breach in the patron-client contract. Some Jesuits were critical of the

\footnotetext{
${ }^{30}$ Eric R. Wolf, "Kinship, Friendship, and Patron-Client Relations in Complex Societies," in The Social Anthropology of Complex Societies, ed. Michael Banton (London: Routledge, 2004), 1-22, here $16-17$.

${ }^{31}$ The Jesuits' preference for not separating enslaved families during the 1838 sale is well documented. Efforts not to separate married couples are also documented. Nonetheless, the Jesuits' definition of "family" as married couples and often children would have appeared narrow within the extended kin networks that developed among enslaved families on the plantations. Moreover, there were numerous contradictions in this system, given enslaved Africans' role as material investments as well as people. See "Fr. Roothaan, S.J. Lays Out the Conditions for the Sale of Slaves, 27 December 1836." GSA 86. Roothaan to McSherry, December 27, 1836, Box 93, Folder 9, MPA. "II Shall Be Obliged to Sell Our Man Not to Separate Man \& Wife': A Jesuit Priest Tries to Keep a Family Together, 1826." GSA 59. Box 61, Folder 9, MPA.

${ }^{32}$ Alice Rebecca Bennett, interview by Carrie Nobel Kline, transcribed from audio CD-R, April 1, 2002, Southern Maryland Folklife Project (SMFP), SlackWater Archive (hereafter SlackWater), St. Mary's College of Maryland (SMCM); https://smcm.contentdm.oclc.org/digital/collection/p4105coll5/id/291 (accessed October 20, 2020).

${ }^{33}$ Horace B. McKenna, "Colored Catholics in St. Mary's County," Woodstock Letters 79, no. 1 (1950): 55-78, here 59. “Louisa Mason Obituary, 1909.” GSA 83. St. Mary's Beacon, July 22, 1909. Farms 1886, Ledger of Farms and County Pastors 1899, Box 14, Addendum to the Maryland Province Archives of the Society of Jesus (MPA ADD), Georgetown University Archives, Washington, DC. Pyne, "Historical Background," 54.

${ }^{34}$ Zwinge, "Negro Slaves," 198.
} 
morality of enslaved Africans on their plantations, particularly sexual infidelity and drunkenness. In 1774, posits Zwinge, Father James Walton sold illegitimate enslaved children at Newtown plantation as a punishment to parents for their sexual infidelity. "It does seem strange," he writes,

that one of the mulatto boys, though born of a negro couple, should have the same name as a tenant, and that several children having the same father should have a different mother, both mothers being alive, and that three of them should have only a mother on the list, the last of them having a very infamous epithet given her. ${ }^{35}$

An 1819-35 baptismal register from Newtown clearly indicates whether "colored" children are illegitimate or born of a lawfully married couple. ${ }^{36}$ Father Peter Kenney wrote in 1831 of adultery, illegitimate children, and a woman of "infamous character" among the enslaved at Bohemia plantation. A man named Jem was known for selling whiskey and other alcohols from his house, described by Kenney as "a sort of tavern." Kenney writes, "not one has been to the Sacraments for 12 yrs except an old woman: seldom is one seen at mass on Sundays: all swear \& curse: 2 are drunk 10 or 12 times in the year." 37 Peter Finn interprets the violation of Christian morality by enslaved Africans as a clear act of resistance to the Jesuits' temporal power and spiritual authority. ${ }^{38}$ The Jesuits probably saw the unorthodox practices of the enslaved population as a poor reflection on their effectiveness as missionaries. These actions, in addition to economic factors, contributed to the sale of enslaved Africans from Bohemia. Kenney investigated the possibility of a sale in 1832, and at least five persons were sold in $1833 .{ }^{39}$

Even as spiritual agents, enslaved Africans struggled and often failed to exercise control over their own bodies. While some enslaved people entered into a patron-client relationship with the Jesuits, others rejected it. Abraham claimed his freedom by escaping from St. Inigoes in 1767, one of many examples of runaways

\footnotetext{
35 Zwinge, "Negro Slaves," 202-3.

${ }^{36}$ Edwin Warfield Beitzell, The Jesuit Missions of St. Mary's County, Maryland, revised ed. (Leonardtown, MD: St. Mary's County Historical Society, 1976), 180-92.

37 "Peter Kenney, S.J.'s Observations on Slave Families at Bohemia, 1831." GSA 57. Box 126, Folder 4, MPA.

${ }^{38}$ Finn, "Slaves of the Jesuits in Maryland," 70-72, 80-81.

39 “"They Want Them [...] For Their Plantations': Fr. Kenney to Fr. Neale on their Plans to Sell a Group of Slaves to a Louisiana Planter, Sept. 10, 1832." GSA 107. P. Kenney to F. Neale, September 10, 1832, Box 63, Folder 17, Item 1, MPA. "The Corporation of Roman Catholic Clergymen Approves the Sale of Slaves from Bohemia Plantation, August 1833." GSA 242. Proceedings of the Corporation of Roman Catholic Clergymen, August 6, 1833, Box 24, Folder 2, MPA.
} 
from Jesuit plantations. ${ }^{40}$ Numerous other enslaved workers also sued for their freedom following the American Revolution, including members of the Queen and Mahoney families at White Marsh plantation, who fought for their freedom in court against Rev. John Ashton. ${ }^{41}$ Clearly slavery was not acceptable to Abraham, Phillis Queen, Charles Mahoney, and many other individuals, who took matters into their own hands.

Unlawfully liberating oneself from slavery was considered a mortal sin. Becca, who had escaped from her enslaver, sought help from Father John Baptist Cary at Georgetown College. While Cary sought to arrange her sale to a new master, he informed Becca that she could not receive sacraments as a result of her actions. ${ }^{42}$ For 272 individuals, this struggle culminated with the Jesuits' abandonment of their plantations as missions through an 1838 slave sale, which would permit them to refocus ministry on white European immigrants. ${ }^{43}$

\section{Segregated Communities}

Nonetheless, African American ministry continued after the Jesuits' slave sale and emancipation. Father William Treacy noted that it was easier to minister to Black Catholics under slavery when they would gather on the plantation, but "since the war the colored folks have taken up little pieces of land here and there in the woods, and along the creeks and road-sides. [...] The priest is obliged to seek them out separately." ${ }^{44}$ Beginning around 1830 , some formerly prominent white families in southern Maryland moved west to locales staffed by fewer Catholic priests. Father James Pye Neale's comments from his time in southern Maryland during the 1870s and 1880s illuminate the resentment he felt toward African Americans in Maryland, who had greater access to the sacraments than his own family in Texas. He wrote:

I can not help thinking how sad it is that while that poor old colored woman who was the first one to whom I gave Communion had many zealous men and women looking after her and instructing her, the descendants of old and

\footnotetext{
40 “Abraham Runs Away, November 16, 1767." GSA 316. Pigskin Manual, 1747-79, Box 3, Folder 15, MPA 3.

${ }^{41}$ William G. Thomas et al., "O Say Can You See: Early Washington, D.C., Law \& Family"; http://earlywashingtondc.org (accessed August 5, 2020).

42 "Fr. Cary Intercedes for Becca, a Runaway Slave, March, 1820." GSA 352. Fr. John Baptist Carey to Fr. Francis Neale, March 21, 1820, Box 59, Folder 8, MPA.

${ }^{43}$ Adam Rothman, "Georgetown University and the Business of Slavery," Washington History 29, no. 2 (2017): 18-22; Murphy, Jesuit Slaveholding, xiv, 164-65.

${ }^{44}$ William P. Treacy, "Historical Points Connected with New-Town Manor and Church, St. Mary's County, Maryland," Woodstock Letters 14, no. 1 (1885): 61-79, here 71.
} 
glorious ancestry, whose family has kept the faith through bloody martyrdom, should grow up and get married without even making their first Communion. ${ }^{45}$

Accounts of late nineteenth-century ministry reveal African Americans' continued devotion to Catholic practices, as well as the Jesuits' beliefs about their spiritual aptitude and racial inferiority. The Jesuit church at St. Nicholas in St. Mary's County, originally built in 1795 , was attended by a primarily Black congregation in the late nineteenth century. Much of the white Catholic population had left the area, replaced by tenant farmers from Virginia. Father John Scully described his first impressions of the church at the turn of the twentieth century: "I had seen it but thought it was a negro meeting house of some kind. [...] Never before had I seen so miserable looking a structure used as a place of worship by Catholics-a decaying frame building, half whitewashed and without a cross." ${ }^{36}$ Maintenance for this church was apparently not a priority for the Jesuits in the decades following the Civil War. Neale ministered there as well, remarking that "the 'darkies' at St. Nicholas' are a fine set; very religious, generally sober and docile. Negroes are naturally religious. ${ }^{47}[\ldots]$ If negroes are taken early and taught religion, I believe they will be as pure as, if not purer than white people." 48 Neale added a caveat that one must allow for their "inferiority in intellect." He also considered his African American parishioners ungrateful, because they did not make the customary financial contributions at the time of sacraments. ${ }^{49}$ Yet Father James Brent Matthews, stationed at St. Inigoes between 1904 and 1918, expressed pride in the African American families from St. Nicholas. When they arrived at a church festival in ox carts, he remarked, "See those people driving two-horse buggies; there are my people." 50 Matthews's comment reflects a paternal attitude toward the spiritual and economic accomplishments of his congregation. Paternalism would have been expected of a priest in this period. Similar language was not, however, used to describe white families.

During the late nineteenth and early twentieth centuries, Catholicism was widespread among African Americans in southern Maryland. The Catholic Church was fully integrated into their social lives and provided numerous outlets- through education, employment, and mutual aid—for Black Catholics to support each other

\footnotetext{
${ }^{45}$ William C. Repetti, "Historical Notes: Letters of Father James Pye Neale," Woodstock Letters 82, no. 3 (1953): 238-70, here 245.

${ }^{46}$ John Scully, "Mission Work around St. Inigo's, MD: A Letter from Father John Scully, S.J.," Woodstock Letters 33, no. 1 (1904): 35-46, here 40.

${ }^{47}$ The idea that African Americans were "naturally" religious was common at that time. See Raboteau, Slave Religion, 56.

${ }^{48}$ P. [James Pye] Neale, “St. Inigo's," Woodstock Letters 17, no. 3 (1888): 288-93, here 291.

${ }^{49}$ Neale, "St. Inigo's," 291-92. Repetti, "Historical Notes," 261.

${ }^{50}$ McKenna, "Colored Catholics," 62.
} 
and improve their economic situation. Traveling to Mass on Sundays offered an opportunity to visit with family, breaking up the mundanity of everyday life. Likewise, church festivals were accessible and enjoyable social events for many families. African Americans were employed in church maintenance, advocated for and taught at Catholic schools, established beneficial societies, and joined religious orders. It is clear that connections forged through church attendance provided avenues for employment. Jim Mason cared for the church and graveyard as the sexton at St. Inigoes, Ignatius Carter served as the sexton at Sacred Heart Church in St. Mary's County, and Alice Bennett cooked for the Jesuits at their St. Michaels residence. Daniel Barnes taught at a colored parochial school in St. Mary's in 188789, and Garner Mahoney advocated for both Christianity and education in an 1899 article in the Saint Mary's Beacon. Black schools at St. Peter Claver (see fig. 1), the Cardinal Gibbons Institute, and St. Joseph enabled access to education; during the twentieth century, some students paid their tuition by working for the sisters (nuns) at St. Joseph after school. Beneficial societies and fraternal organizations like the Knights of St. Jerome provided economic support to care for the sick and bury the dead during times of financial instability. Moreover, numerous African American women from St. Mary's County joined the Colored Order of Oblate Sisters of Providence in Baltimore during the 1880s and 1890s. About two dozen women, some of whom, like Harriet Maize (Sister Aloysia), had been enslaved, educated the African American population of Baltimore. ${ }^{51}$

The Jesuits supported these spiritual and economic efforts to uplift the Black Catholic community. They established and supported numerous African American schools, including St. Peter Claver and the Cardinal Gibbons Institute. Father John LaFarge, who was instrumental in the establishment of these schools, also held secret interracial meetings in order to dispel myths about racial difference. Matthews promoted land ownership and economic self-sufficiency among African Americans. After Theresa Cassagnol's father lost his farm when the US Navy installed

\footnotetext{
${ }^{51}$ Scully, "Mission Work," 42. Beitzell, Jesuit Missions (revised), 213-15. Pyne, "Historical Background," 51; Ernest Webster Dyson, interview by Andrea Hammer and Paula Johnson, transcribed from cassette tape, February 26, 1987, Southern Maryland Documentation Project (SMDP), SlackWater, SMCM; https://smcm.contentdm.oclc.org/digital/collection/p4105coll5/id/59 (accessed October 20,2020). Alice Rebecca Bennett, interview by Gloria Pettaway, transcribed from cassette tape, August 1, 1991, SMDP, SlackWater, SMCM; https://smcm.contentdm.oclc.org/digital/collection/p4105coll5/id/228 (accessed October 20, 2020); Nicholas Vincent Biscoe, interview by Catherine Brenda Coates, transcribed from audio file, March 6, 1997, Unified Committee for AfroAmerican Contributions Oral History Collection (UCAACOHC), SlackWater, SMCM; https://smcm.contentdm.oclc.org/digital/collection/p4105coll5/id/381 (accessed October 20, 2020); Bennett, interview, 2002; Helen Louise Fenwick, interview by Catherine Hinebaugh, transcribed from cassette tape, April 3, 1986, SMDP, SlackWater, SMCM; https://smcm.contentdm.oclc.org/digital/collection/p4105coll5/id/99 (accessed October 20, 2020); Sarah Evelyn Mason Butler, interview by Catherine Brenda Coates, transcribed from cassette tape, March 13, 1997, UCAACOHC, SlackWater, SMCM; https://smcm.contentdm.oclc.org/digital/collection/p4105coll5/id/390 (accessed October 20, 2020).
} 
the air station at Patuxent River, Father Horace McKenna helped him get a new farm. McKenna also used funds from the collection plate to help parishioners who struggled to pay their rent and utility bills. ${ }^{52}$

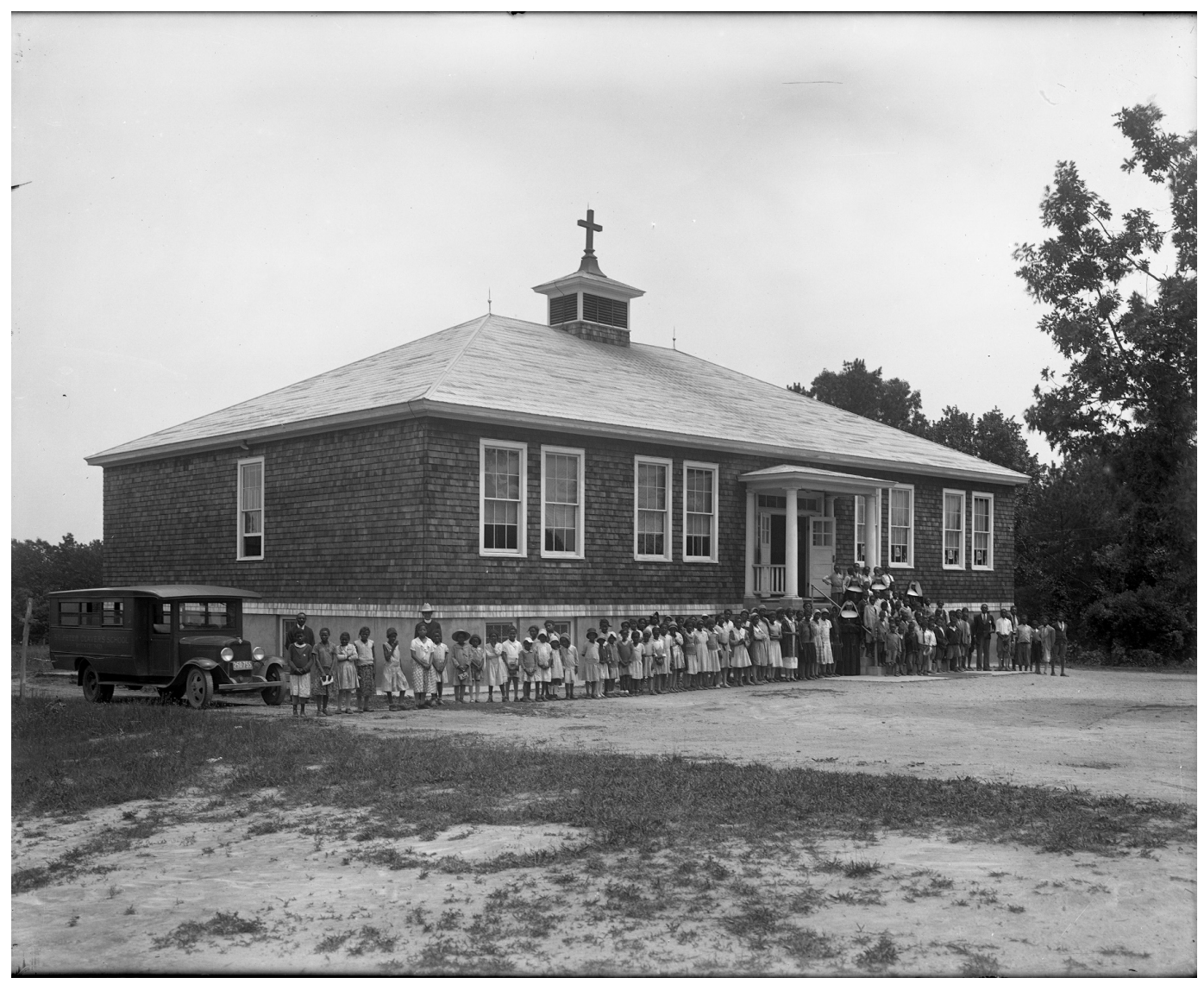

Figure 1. Students at St. Peter Claver School. Ridge, Maryland, 1933. Image Courtesy of John Brosnan, S.J., Photographic Collection. Digital Georgetown, Woodstock Theological Library, Washington, D.C.

Nonetheless, parish communities and religious institutions in St. Mary's County had become increasingly segregated in the decades following the Civil War. By the turn of the twentieth century, racial distinctions within parishes had become very clear. Many members of the clergy, including Archbishop of Baltimore Cardinal James Gibbons, considered this a virtue: "I never witnessed anywhere else the white race so kind and considerate to the colored, nor the colored race so respectful and deferential to the white, for there was no attempt at these weekly gatherings to level the existing social distinctions." He argued that Black deference to white superiority at southern Maryland churches precluded incidences of lynching seen elsewhere

${ }^{52}$ McKenna, "Colored Catholics"; Bennett, interview, 2002; Theresa Smith Cassagnol, interview by Carol Locke-Endy, transcribed from audio file, June 1, 2002, UCAACOHC, SlackWater, SMCM; https://smcm.contentdm.oclc.org/digital/collection/p4105coll5/id/393 (accessed October 20, 2020). 
in the south. ${ }^{53}$ Although the Mass was integrated, seating was not: a rear gallery for African Americans was added to St. Inigoes church between 1816 and 1849, and side galleries were added in 1852 . The cemetery was also segregated. ${ }^{54}$ McKenna wrote: "It is true that it was the sacraments and not the seating that united the white and Negro Catholic people." $" 55$

Unspoken rules shaped Black Catholics' experience of the Mass: white congregants always received Communion first and were hostile when African Americans disregarded segregated seating. Even into the mid-twentieth century, Black Catholics often could not serve as altar boys or be officially installed as acolytes. George Forrest remembered that none of the holy images in the church looked like him. ${ }^{56}$ Community events, such as the distribution of gifts to children from the parish Christmas tree, followed the same principles of segregation: Black children received gifts only after the white children had finished. ${ }^{57}$

At St. Inigoes, Father William Tynan established two sodalities in 1900: the white sodality was devoted to St. Michael, while the Black sodality was under the patronage of St. Peter Claver. ${ }^{58}$ The Black community at St. Inigoes initially met at the Biscoe home on Smith's Creek (Beachville), built a community and sodality hall on land donated by the Biscoe family, and established their own choir. Tensions between the two sodalities came to a head in Christmas of 1902 over disputes about the communal reception of the Eucharist and the prominence of the Black choir. As

${ }^{53}$ Baltimore Sun, 1905. Box 15, Folder 7, MPA. There were, in fact, several lynchings of African Americans in southern Maryland, including a cook named Charles Whitley/Whittle in 1886, and Benjamin Hance in 1887. Furthermore, Alexander Mason, employed as a laborer or carpenter at St. Inigoes plantation in 1850 and 1860, was murdered when traveling between St. Nicholas Church and St. Inigoes in 1860, perhaps because of his recent enlistment in the Union Army. Jonathan M. Pitts, "Bringing a Dark Chapter to Light: Maryland Confronts Its Lynching Legacy: Baltimore Sun," Baltimore Sun, September 25, 2018; https://www.baltimoresun.com/news/maryland/bs-md-lynching-in-maryland-20180919-htmlstory.html (accessed August 5, 2020). Federal census 1850, 1860. "Louisa Mason Obituary, 1909." GSA 83.

${ }^{54}$ Walsh, "Resurrection," 129. Joseph Agonito, "St. Inigoes Manor: A Nineteenth Century Jesuit Plantation," Maryland Historical Magazine 72, no. 1 (Spring 1977): 83-98, here 89.

${ }^{55}$ McKenna, "Colored Catholics," 57.

${ }^{56}$ George Gaither Forrest, interview by Carol Locke-Endy, transcribed from cassette tape, June 6, 2003, UCAACOHC, SlackWater, SMCM; https://smcm.contentdm.oclc.org/digital/collection/p4105coll5/id/399 (accessed October 20, 2020); James Alexander Forrest Sr., interview by Bob Lewis, transcribed from cassette tape, February 25, 2003, UCAACOHC, SlackWater, SMCM; https://smcm.contentdm.oclc.org/digital/collection/p4105coll5/id/398 (accessed October 20, 2020); Everlyn Louise Holland, interview by Merideth M. Taylor, transcribed from cassette tape, November 16, 1996, UCAACOHC, SlackWater, SMCM; https://smcm.contentdm.oclc.org/digital/collection/p4105coll5/id/416 (accessed October 20, 2020); Mary Louise Barnes Fleming, interview by Stephanie Culen, transcribed from cassette tape, March 9, 1987, SMDP, SlackWater, SMCM; https://smcm.contentdm.oclc.org/digital/collection/p4105coll5/id/71 (accessed October 20, 2020).

${ }^{57}$ McKenna, "Colored Catholics," 57.

${ }^{58}$ St. Peter Claver was a seventeenth-century Spanish Jesuit known for his ministry to slaves in Colombia, and was canonized in 1888 . 
a result, the African American community began to hear Mass at the sodality hall, and by 1905 a separate church of St. Peter Claver was officially established. ${ }^{59}$

Jesuit priests sent to St. Mary's County during the twentieth century remarked on the rules that governed their interactions with Black and white parishioners. Scully remarked, after inquiring from the white parishioners how he should "draw the line in dealing with the blacks," that he could say Mass at the houses of Black Catholics, but could not eat a meal with them. He wrote, "“If you did that, Father,' it was said to me, 'we should have them calling on us and resenting it if we did not receive them." 60 A Jesuit assigned to St. Mary's County in the midtwentieth century wrote: "I felt that I had the alternatives that a doctor would have when he is sent to an area beset by a plague that has been going on so long that the community at large would not admit that they were sick." 61 He was told by fellow clergy and community members alike that he would be "run out of the territory" if he tried to unify Black and white Catholics. ${ }^{62}$ Both Father Richard McSorley and Father Francis Walsh, who was stationed at St. Peter Claver in the 1970s and 1980s, likened parish segregation in St. Mary's County to a spiritual or ecclesiastical Vietnam: a messy problem without a clear solution. ${ }^{63}$ By allowing segregation to continue in the early twentieth century, the Jesuits cemented racial distinctions that continued throughout the twentieth century. Nonetheless, Walsh considered St. Peter Claver parish to be the spiritual heir to the Jesuit mission at St. Inigoes, a strong testament not only to the centrality of the Catholic Church to African Americans but also the importance of Black Catholics to the continuation of the St. Inigoes mission community.

\section{Materiality of Catholic Practice}

Material objects were integral to Jesuit missionary efforts among African Americans in southern Maryland. It is clear that members of the Black Catholic community-like their West African ancestors - saw such objects as important spiritual tools, using them to communicate with supernatural beings. While objects like medals were often distributed freely, rosary beads, scapulars, and other costly objects were typically purchased. Immediately following his discussion of African American religious practice at St. Thomas, Grivel noted that he did not have any rosaries, images, medals, or other objects, but the other Jesuits were importing some

\footnotetext{
59 Walsh, "Resurrection," 153-57. McKenna, "Colored Catholics,”60-62.

${ }^{60}$ Scully, "Mission Work," 44.

${ }^{61}$ Richard T. McSorley, “A Challenge to Sincerity,” Woodstock Letters 97, no. 3 (1968): 335-44, here 335 .

62 McSorley, "Challenge to Sincerity," 336.

${ }^{63}$ Walsh, "Resurrection," 11.
} 
for him. ${ }^{64}$ When a boat arrived to carry the enslaved Africans sold from Newtown in 1838, Father Peter Havermans noted that people came to him, asking for rosaries, medals, and crosses to carry with them to Louisiana ${ }^{65}$ The slave quarters at St. Inigoes were moreover "garnished with some holy prints." ${ }^{66}$ Neale, describing a drive through the St. Mary's County countryside, wrote, "I dash on after scattering palms and medals among the Catholics and others. ${ }^{{ }^{67}}$ A few decades later, Scully described his challenges navigating the same county roads. After receiving helpful directions from an African American woman, he wrote, "what a relief that answer gave me! and how I wished I had a scapulars or a beads [sic] to give that good woman. ${ }^{968} \mathrm{He}$ also notes that he sold scapulars and beads after Mass and benediction at the mission churches. ${ }^{69}$ Neale also reports that African Americans came to him for holy water, beads, "scaffols," and "dem little hearts" after Mass. ${ }^{70}$ Black women, in particular, used these objects in prayer. An anonymous author observed in 1869 that the devout African American parishioners at St. Inigoes crowded the galleries and "kept up a great rattling with their large rosaries." " A March 22, 1888 death notice from the St. Mary's Chronicle states, "Sunday morning last, Sarah Ann Greenwell, Colored, was found kneeling by her bedside, with a rosary in her hand, dead." 72 Rosaries, scapulars, medals, holy images, and holy water could be given as gifts by Jesuits but were also freely sought out and used by African Americans during this period. In the twentieth century, individuals had diverse attitudes toward rosaries. Alice Bennett disliked praying the rosary as a child, describing days when her family said the rosary instead of going to church as "like a wake." Mary Louise Fleming remembered saying the rosary as a family after dinner every night during the Lenten season. Later in her life, she continued the practice, driven not by obedience but by the rosary's enjoyable familiarity. ${ }^{73}$

\footnotetext{
64 "Slavery at St. Thomas Manor: Fr. Grivel to Fr. Roothaan, 1831." GSA 296.

65 “"What Will Become of Me?': Fr. Havermans Reports on the Anguish of the Slaves, October 20, 1838 and November 12, 1838." GSA 208. Havermans to Roothaan, November 12, 1838, ARSI, Provincia Maryland, 1007-I, 9.

${ }^{66}$ Zwinge, "Negro Slaves," 197.

${ }^{67}$ Repetti, "Historical Notes," 262. Sarah Hewlett remembers that her mother would burn candles and palms during bad storms, a curious and unorthodox use of these holy objects. Sarah Evelyn Hewlett, interview by Andrea Hammer, transcribed from cassette tape, July 7, 1986, SMDP, SlackWater, SMCM; https://smcm.contentdm.oclc.org/digital/collection/p4105coll5/id/124 (accessed October 20, 2020).

${ }^{68}$ Scully, "Mission Work," 36.

${ }^{69}$ Scully, "Mission Work," 36, 40.

${ }^{70}$ Neale, "St. Inigo's," 290. Reported in dialect, these terms are challenging to decipher. "Scaffols" may be scapulars, necklace-like objects that contain religious images or prayers and may carry religious indulgences. "Dem little hearts" may refer to depictions of the Sacred Heart of Jesus, shown as crowned with thorns, or to the heart of Mary, pierced by a sword.

71 "St. Mary's (From the Catholic World for June, 1869)," Saint Mary's Beacon, July 1, 1869, Thursday morning edition, Available through Historic Saint Mary's City.

${ }^{72}$ Beitzell, Jesuit Missions (revised), 214.

${ }^{73}$ Bennett, interview, 1991; Fleming, interview, 1987; see also Biscoe, interview, 1997.
} 
Similar Catholic devotional objects have also been uncovered from Maryland archaeological contexts either directly or possibly associated with African Americans. These objects were primarily recovered from disturbed or mixed fill layers, making it difficult to produce specific dates as to when they would have been acquired or used, or associate them with particular individuals. The majority of artifacts, however, date to the nineteenth or early twentieth centuries. These artifacts - medals, a statue, a rosary, a cross, and a crucifix plaque - were in most cases excavated from plantation quarter or post-bellum tenant houses, on land that was owned by both Protestants and Catholics. Each site is also located in close proximity to a Jesuit plantation or church.

Nineteenth- and early twentieth-century religious medals can be identified by their subject matter (discussed below) and by "parallel" bails used to hang or attach a medal, which were uncommon until the nineteenth century. ${ }^{74}$ They have been identified at sites including the Carroll family occupation at Susquehanna (18ST399, 1832-1940 context) and Rousby (18ST751, 1854-1900 context); the Brome family residence at the Brome-Howard House (18ST1-13, 1840-1900) and an unnamed tenant site (18ST1-139, mid-to-late nineteenth century); Charles' Gift (18ST704, 1832-1943 context); the Harman family occupation at Wilderness (18AN596, 1832-1950s context); and the Dulany family home at Shuter's Hill (44AX175, 1832-1908 context). Almost all of these medals depict Jesus's mother, Mary. In total, at least seven are "miraculous medals," made starting in 1832, following the apparition of the Virgin Mary to Zoe Labore in 1830. The medal from Rousby commemorates Pope Pius IX's (r.1846-78) declaration of Mary's immaculate conception in 1854. The remaining two medals depict St. Benedict. ${ }^{75}$ It is notable that the imagery on medals from nineteenth- and twentieth-century contexts, most of which depicts the Virgin Mary, is remarkably different from seventeenth- and eighteenth-century medals excavated from St. Mary's City and St. Inigoes, which more often depict saints and images associated with the CounterReformation or the Society of Jesus. ${ }^{76}$

The strongest evidence for the use of Roman Catholic devotional artifacts by African Americans, however, comes from three sites: Northampton Quarter and Willow Grove in Prince George's County, and St. Inigoes in St. Mary's County. Other contexts are less certain and could be associated with anyone living on or visiting the remaining plantations. Seven artifacts-five medals, a fragment of a

\footnotetext{
${ }^{74}$ Timothy B. Riordan, “'To Excite the Devotion of the Catholics': The Use and Meaning of Catholic Religious Medals in the Colonial Period," Historical Archaeology 49, no. 4 (2015): 71-86, here 79.

${ }^{75}$ Sara Rivers Cofield, "Religious Artifacts," Diagnostic Artifacts in Maryland, May 14, 2014; https://apps.jefpat.maryland.gov/diagnostic/SmallFinds/ReligiousArtifacts/index-religiousartifacts.htm (accessed August 5, 2020). Garrett Fesler, personal communication, May 4, 2018.

${ }^{76}$ Riordan, "To Excite the Devotion." Rivers Cofield, "Religious Artifacts."
} 
bone rosary, and a bone cross - were excavated from two houses at the Northampton Quarter, part of a plantation owned by the Episcopal Sprigg family between 1673 and 1865, and the Fairfax family between 1865 and 1959. The twenty-four by twenty-seven-foot frame duplex quarter, documented in the 1798 direct tax as "Negro House 26 by 24," was probably constructed in the late eighteenth century, while the twenty-four by forty-two-foot brick quarter was probably constructed between 1820 and the 1850s. An African American woman named Elizabeth Hawkins lived at Northampton with her husband Robert in 1870 , and her family remained there through the early twentieth century. ${ }^{77}$ Lizzie and Robert's daughter Rosa was baptized Catholic, and the documentation for her baptism was kept in the parish records at nearby Holy Family Catholic Church, established by the Jesuits as a mission to African American tenant farmers. ${ }^{78}$ Although there is no conclusive evidence that Lizzie, Robert, and their family attended Mass at Sacred Heart Church at White Marsh (twelve miles away) or Holy Family Church (four miles away), it seems likely given available evidence. The four non-corroded medals depict the Virgin Mary (see fig. 2), suggesting that such medals were the most widely available, and perhaps that at least one member of the family practiced a devotion to Mary. A Georgetown College button and a Mary-St. Francis Xavier medal indicate a particular association with the Jesuits. ${ }^{79}$

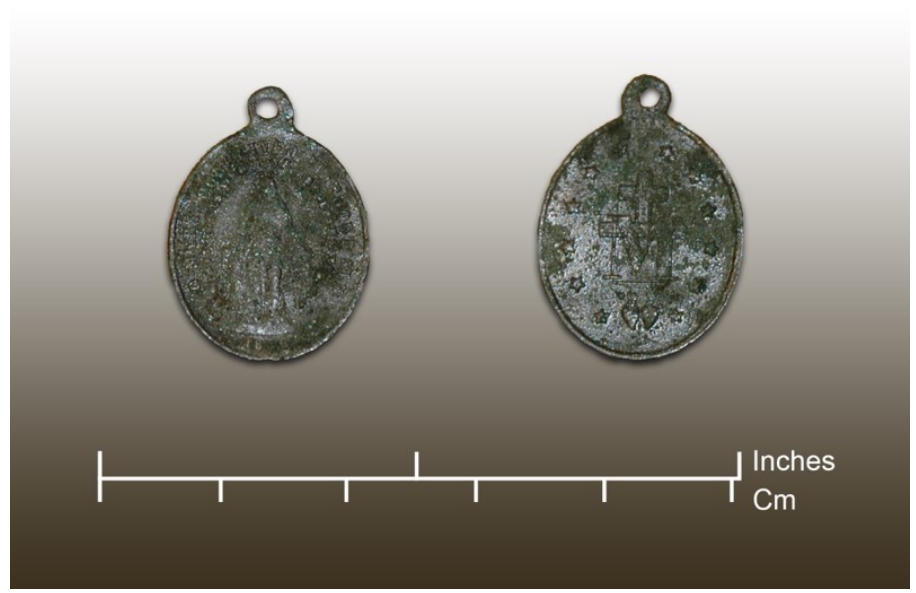

Figure 2. Obverse and reverse of a Miraculous medal from Northampton Quarter. Production of these medals began in 1832, and commemorated the apparition of the Virgin Mary in 1830 Paris. Image by Kristin M. Montaperto, 2010.

A holy family medal and a small figurine of the Virgin Mary (see fig. 3) were excavated from two quarter or tenant houses on Willow Grove plantation, located a

\footnotetext{
${ }^{77}$ Kristin Marie Montaperto, "Public Archaeology and the Northampton Slave Quarters: Community Collaboration" (PhD diss., American University, 2012), 46-48.

${ }^{78}$ Montaperto, "Public Archaeology," 201-2.

${ }^{79}$ Montaperto, "Public Archaeology," 192-200.
} 
few miles from White Marsh plantation. The land was held by the Protestant Bowie family from the early eighteenth century through the late twentieth century. ${ }^{80}$ Both artifacts were excavated from frame structures with fieldstone foundations. The holy family medal was found in structure 5, which measured twenty-four by twenty-eight feet and is interpreted as a tenant or overseer's house. The statue was found outside of structure 5, which measured sixteen by twenty-two feet and was interpreted as a post-bellum tenant house. ${ }^{81}$ Although the archaeological research team carrying out the excavations did not identify the site's residents, these individuals were likely enslaved Africans or African American tenant farmers. African American tenant farmers in nearby Collington were known to walk to a Catholic church in Bowie, most likely Sacred Heart Church at White Marsh. ${ }^{82}$

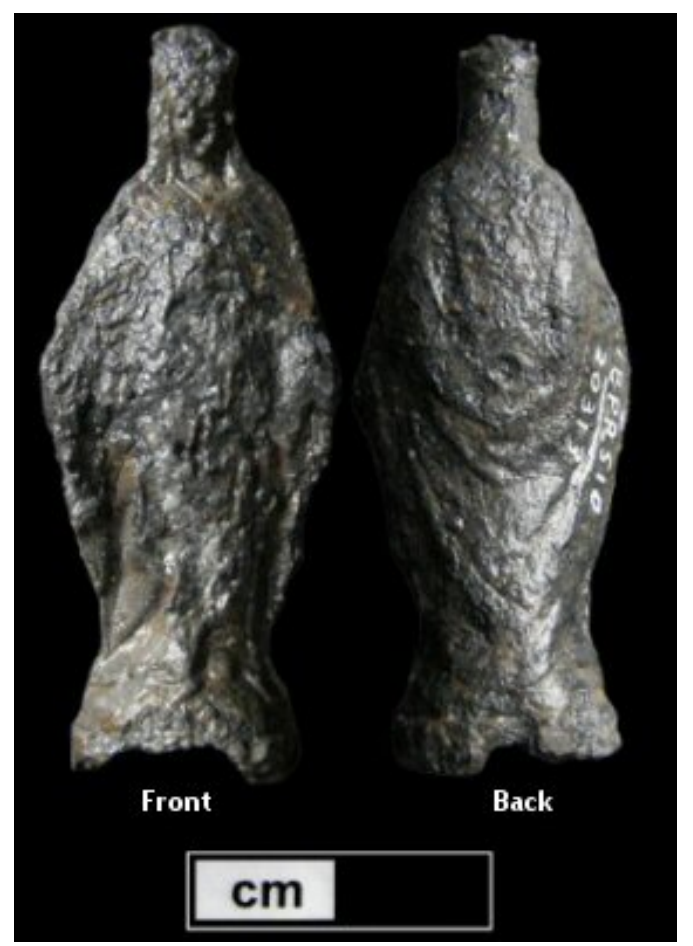

Figure 3. Obverse and reverse of a Virgin Mary figurine from Willow Grove tenant house. Image courtesy of the Maryland Historical Trust, Maryland Archaeological Conservation Laboratory.

\footnotetext{
${ }^{80}$ Matthew H. Gill et al., "Phase III Archaeological Data Recovery at the Willow Grove Site (18PR510), Prince George's County, Maryland," Report Prepared for Mid-Atlantic Companies, Rockville, MD (Laurel, MD: Greenhorne \& O'Mara, May 2006), 22-23.

${ }^{81}$ Gill et al., "Willow Grove," 90-99.

${ }^{82}$ Gill et al., "Willow Grove," 37.
} 
In the rear yard of a small nineteenth- to twentieth-century house site at St. Inigoes plantation, archaeologists excavated an "INRI" plaque ${ }^{83}$ with a posterior tack that would have been attached to a wooden crucifix (see fig. 4).

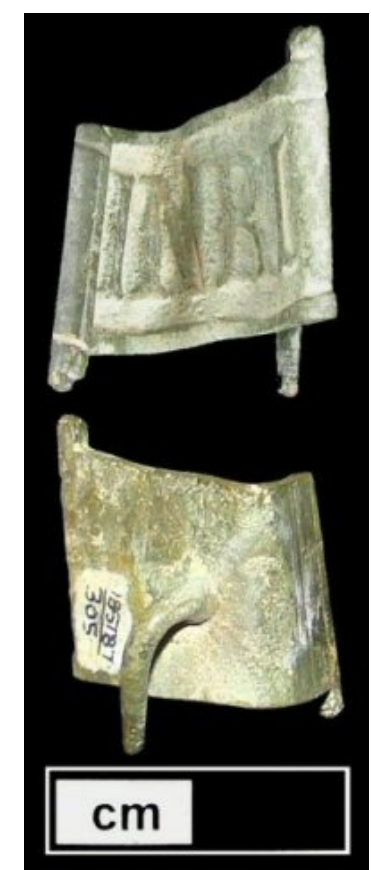

Figure 4. INRI Plaque from Mahoney-Mason-Raley house at St. Inigoes. The plaque would have been attached to a crucifix. Image courtesy of Naval Air Station Patuxent River's Webster Field Annex, Naval District Washington.

Oral histories confirm that the Raley family lived at this site in the early twentieth century. Before this, this house was likely the residence of Louisa Mahoney Mason and her mother, who evaded the 1838 slave sale and lived at St. Inigoes "in a small house near the ice pond" after emancipation. ${ }^{84}$ Louisa and her husband Alexander Mason may also have lived in this house with their children Daniel, Ann, Charity, Thomas, Josephine, and Robert. ${ }^{85}$ The "INRI" plaque was probably on a crucifix

83 "INRI" are initials for the Latin phrase "Iesus Nazarenus, Rex Iudaeorum," which translates to "Jesus the Nazarene, King of the Jews." According to the Bible, this phrase was placed above Jesus when he was crucified. The letters "INRI" are frequently placed above the crucified body of Jesus on crucifixes.

${ }^{84}$ Laura J. Galke and Alyssa L. Loney, "Phase I Archaeological Investigations Aboard Webster Field Annex: NAS PAX, St. Mary's County, Maryland," Report presented to Natural Resources Branch Environmental and Natural Resources Division Department of Public Works Naval Air Station Patuxent River (St. Leonard, MD: Jefferson Patterson Park and Museum Maryland Historic Trust, 2000), 133-38. Beitzell, Jesuit Missions, 133.

${ }^{85}$ Alexander Mason is listed immediately after the Jesuit household in the 1850 census and as part of the household in the 1860 census, but Louisa and the children were instead listed in the slave schedule. "Louise Mason and Her Children: The Last Slaves of the Maryland Jesuits." GSA 69. Agnes Kane Callum, Slave Statistics of St. Mary's County Maryland, 1864, Commissioner George 
displayed in the Mahoney-Mason or Raley house-pious Catholics were among both families - until it was lost or discarded.

There are several commonalities within these collections of Catholic artifacts. First, they were excavated on or near Jesuit plantations, and usually within ten miles of a Jesuit church. Second, nearly all of the artifacts are from Maryland. The exception is the miraculous medal from Shuter's Hill, located about two miles from St. Mary Catholic Church in Alexandria, Virginia, established by the Jesuits in $1795 .{ }^{86}$ Medals or other Catholic artifacts have not been recovered from otherwise similar plantation sites in Virginia. ${ }^{87}$ The spatial distribution of these artifacts, including their presence at African American sites, is not a coincidence. These artifacts were most likely distributed by Jesuit priests to faithful Catholics and potential converts during the nineteenth and early twentieth centuries, a period during which Jesuit missionary efforts in Maryland focused on African Americans. The specific ways these artifacts were used is unclear in most cases, since they were located in disturbed or fill contexts. The artifacts may have been intentionally placed, lost, or perhaps discarded when they were no longer seen as useful.

The vast majority of objects — medals, a rosary, and a statue - are connected to the Virgin Mary and would have been used in associated devotions and prayers. African American Catholics may have venerated Mary as "queen of angels"-a phrase inscribed on the medal from the Brome tenant house- or identified with her as a devoted and sacrificing mother. The obverse of the miraculous medals depicts Jesus's heart, crowned with thorns, and Mary's heart, pierced by a sword. These images reminded bearers of the suffering of both Jesus and Mary, an outlook that may have brought comfort to Black Catholics facing the painful realities of slavery and segregation. The person who requested "dem little hearts" from Father Neale was probably referring to similar depictions of the Sacred Heart of Jesus or Immaculate Heart of Mary. The presence of Mary — as a queen, as a mother, and as a suffering protector and intercessor-was clearly an important component of Black Catholic devotions in Maryland. Deep spiritual commitments and beliefs, the legacy of Catholic upbringing, are also clear in numerous oral history interviews. As Agnes Blackwell remembered, "we love our religion." 88

B. Dent, Maryland State Archives. GSA 83. Federal Census 1850, 1860. "Louisa Mason Obituary, 1909." GSA 83.

${ }^{86}$ Religious artifacts recovered by archaeologists and collectors at sites in Virginia include a St. Christopher thimble case, a mother of pearl crucifix, and a St. Hubert/Polish Eagle medal. All of these artifacts are from Civil War camp or battlefield sites associated with Union occupations. Jolene Smith, personal communication, July 20, 2018. VCRIS 44FK0568, 44NH0226, 44SP0665.

${ }^{87}$ Leslie Cooper, personal communication, May 23, 2018. The only exception is black faceted glass beads, possibly from a rosary and recovered overlying a grave at the Mount Vernon slave cemetery. Mount Vernon is within ten miles of the Jesuit parish in Alexandria. Lily Carhart, personal communication, June 21, 2019.

${ }^{88}$ George Purnell Frederick Sr., interview by Richard Portee, transcribed from cassette tape, November 16, 1996, UCAACOHC, SlackWater, SMCM; https://smcm.contentdm.oclc.org- 


\section{Conclusion}

When I mention, among Catholic or Jesuit historians, that I study the Jesuits' plantations in Maryland, my statement fills the room with an uncomfortable silence. It is a silence of regret and embarrassment shared by Jesuit scholars and scholars of Jesuits. The Maryland mission represents the failures of accommodation, through slavery and segregation. It is nonetheless important to acknowledge how the Maryland Jesuits approached issues of race in the past, in order to determine how to address the legacy of those decisions today_not least in recognizing and atoning for the sin of slavery. While the Maryland mission has been interpreted as a failure, its poignant legacy is nonetheless clear among the members of St. Peter Claver parish in southern Maryland, or among the descendants of enslaved Africans in Maringouin, Louisiana. In Maryland, the long-term success of a mission to African Americans must be juxtaposed with the economic and moral failures of plantation slavery and segregation.

With few first-person accounts, it is impossible to know exactly what individual African Americans believed, and the ways that beliefs were influenced by West African spirituality or Christianity. It is clear, however, that many enslaved Africans living on or surrounding Jesuit plantations converted to Christianity, baptized their children, served as godparents, were married in the church, taught their children prayers, went to confession, and attended Mass. These decisions were most likely influenced by spiritual beliefs as well as efforts to negotiate power relationships. Obeying religious precepts could foster feelings of moral integrity and selfworth, leading individuals like Louisa Mason to feel that, after a lifetime of service and loyalty, they had earned a requiem Mass and burial in a predominantly white cemetery. After emancipation, African Americans continued to practice Catholicism but also used networks established through the Catholic Church-like similar networks documented for Quaker William Cooper and Presbyterian William Mann - to gain access to employment and uplift their communities through education, mutual aid societies, and the emotional or moral density that came from communal prayer and music. Despite a prevalent belief in their racial inferiority, Jesuit priests played an integral role in ministering to African Americans, recognizing their spiritual dignity, and supporting numerous educational and economic efforts. Archaeological evidence of nineteenth- and twentieth-century devotional artifacts shows that these efforts were widespread. Many of the religious medals

/digital/collection/p4105coll5/id/403 (accessed October 20, 2020); Fleming, interview, 1987; Agnes Geneva Chase Blackwell, interview by Joyce Blackwell, transcribed from CD-R, November 4, 1996, UCAACOHC, SlackWater, SMCM; https://smcm.contentdm.oclc.org/digital/collection/p4105coll5/id/382 (accessed October 20, 2020). 
and other Catholic objects found at nineteenth- and twentieth-century archaeological sites in southern Maryland originated with Jesuit priests. Based on their ancestral traditions, African Americans likely engaged with spiritual presences in ways that were distinct from Euro-American Catholics. They clearly, however, attributed importance to spirituality, believed in the power of sacraments and the presences of saints and angels. Black Catholic spirituality is one of the most significant legacies of the Jesuit mission in southern Maryland, albeit one with a painful history. 